https://doi.org/10.52058/2786-5274-2021-2(2)-211-219

Матвсєва Катерина Сергіївна кандидат педагогічних наук, доцент кафедри іноземних мов, Миколаївський національний аграрний університет, вул. Георгія Гонгадзе, 9, м. Миколаїв, 54000, тел.: (051) 240-91-31, e-mail: matveeva@mnau.edu.ua, https://orcid.org/0000-0003-0974-3022

Марченко Дмитро Дмитрович кандидат технічних наук, заступник декана 3 навчальної роботи інженерно-енергетичного факультету, доцент кафедри тракторів та сільськогосподарських машин, експлуатації і технічного сервісу, Миколаївський національний аграрний університет, вул. Георгія Гонгадзе, 9, м. Миколаїв, 54000, тел.: (051) 240-91-31, e-mail: marchenkodd@ mnau.edu.ua, https://orcid.org/0000-0002-0808-2923

\title{
ПЕДАГОГІЧНІ НАВИЧКИ ЯК ЕЛЕМЕНТ ПРОФЕСІЙНОЇ КОМПЕТЕНТНОСТІ ВИКЛАДАЧІВ ІНОЗЕМНИХ МОВ
}

Анотація. У більшості досліджень останніх років 3 проблем оцінки рівня професійної підготовки педагогів, в тому числі і вчителів іноземних мов, у якості основної крітеріальної характеристики цього феномена виступає професійна компетентність. Вона представляє собою досить складне інтегративне психологопедагогічне явище, що містить у собі, на думку різних дослідників, різні компоненти: власне психологічні (мотиваційний та поведінковий), когнітивні, методичні, полікультурні і т.П. Ряд авторів включають в якості безпосередніх складових професійно-педагогічної компетентності відповідні педагогічні навички. Інші дослідники при аналізі структури професійної компетентності педагогів припускають у ній наявність подібних навичок лише опосередковано, відводячи їм другорядну роль.

Таким чином, можна зробити висновок, що до сих пір не існує загальновизнаного визначення ролі та місця вироблення педагогічних навичок у процесі формування професійної компетентності викладачів. Можна припустити, що тільки виділення педагогічних навичок в їі самостійну складову дозволить чітко й однозначно визначити їх значення в структурі цього інтегративного поняття. Це обумовлено, по-перше, тим, що підвищення професійної компетентності неможливо без продуктивної практичної діяльності. А вона, в свою чергу, багато в чому залежить від оволодіння відповідними навичками, без яких, навіть у випадку оволодіння знаннями й уміннями, така діяльність буде малоефективною. По-друге, нелінійна взаємодія надбаних професійних знань, умінь та навичок у процесі формування і вдосконалення професійної 
компетентності викликає необхідність розглядати їх як самостійні, хоча й взаємопов'язані феномени. По-третє, навички можуть входити в різні компоненти професійної компетентності. Таким чином, професійні навички, в тому числі й педагогічні, відіграють самостійну і досить важливу роль у структурі професійної компетентності.

Ключові слова: педагогічні навички, компетентність, професійнопедагогічна компетентність, іноземна мова, порівняльний аналіз.

Matvyeyeva Kateryna Serhiivna Candidate of Pedagogical Sciences, Associate Professor of the Department of Foreign Languages, Mykolayiv National Agrarian University, George Gongadze St., 9, Mykolayiv, 54000, tel.: (051) 240-91-31, e-mail: matveeva@mnau.edu.ua, https://orcid.org/0000-0003-0974-3022

Marchenko Dmytro Dmytrovych Candidate of Technical Sciences, Deputy Dean for Academic Affairs of the Faculty of Engineering and Energy, Associate Professor of Tractors and Agricultural Machinery, Operation and Technical Service, Mykolayiv National Agrarian University, George Gongadze St., 9, Mykolayiv, 54000, tel.: (051) 240-91-31, e-mail: marchenkodd@mnau.edu.ua, https://orcid.org/00000002-0808-2923

\section{PEDAGOGICAL SKILLS AS AN ELEMENT OF PROFESSIONAL COMPETENCE OF FOREIGN LANGUAGE TEACHERS}

Abstract. In most studies in recent years on the problems of assessing the level of professional training of teachers, including foreign language teachers, as the main criterion characteristic of this phenomenon is professional competence. It is a rather complex integrative psychological and pedagogical phenomenon, which contains, according to various researchers, different components: the actual psychological (motivational and behavioral), cognitive, methodological, multicultural, etc. A number of authors include relevant pedagogical skills as direct components of professional and pedagogical competence. Other researchers in analyzing the structure of professional competence of teachers suggest the presence of such skills only indirectly, giving them a secondary role.

Thus, we can conclude that there is still no generally accepted definition of the role and place of development of pedagogical skills in the process of forming the professional competence of teachers. We can assume that only the allocation of pedagogical skills in its independent component will clearly and unambiguously determine their importance in the structure of this integrative concept. This is due, firstly, to the fact that the increase of professional competence is impossible without productive practical activities. And it, in turn, largely depends on the acquisition of appropriate skills, without which, even in the case of mastering knowledge and skills, such activities will be ineffective. Secondly, the nonlinear interaction of acquired 
professional knowledge, skills and abilities in the process of formation and improvement of professional competence makes it necessary to consider them as independent, although interconnected phenomena. Third, skills can be included in various components of professional competence. Thus, professional skills, including pedagogical, play an independent and very important role in the structure of professional competence.

Keywords: pedagogical skills, competence, professional and pedagogical competence, foreign language, comparative analysis.

Постановка проблеми. У більшості досліджень останніх років 3 проблем оцінки рівня професійної підготовки педагогів, в тому числі і вчителів іноземних мов, у якості основної крітеріальной характеристики цього феномена виступає професійна компетентність. Вона являє собою досить складне інтегративне психолого-педагогічне явище, що містить у собі, на думку різних дослідників, різні компоненти: власне психологічні (мотиваційний та поведінковий), когнітивні, методичні, полікультурні і т.п.

Місце педагогічних навичок у структурі професійно-педагогічної компетентності не отримало однозначного розуміння в сучасній науковій літературі. 3 одного боку, їх можна вважати безпосередньою складовою вище згаданої компетентності. 3 іншого, - професійні навички можливо розглядати лише як другорядні елементи іiі різних перерахованих вище компонентів. У подібній ситуації невизначеності видається цікавим провести порівняльний аналіз позицій окремих дослідників з цього питання і спробувати обгрунтувати власне бачення ролі педагогічних навичок у структурі професійної компетентності на прикладі викладачів іноземних мов.

Аналіз останніх досліджень і публікацій. На жаль, роль різних педагогічних навичок як невід'ємної складової професійної компетентності викладачів, в тому числі і викладачів іноземних мов, не отримала повноцінного освітлення в сучасній науково-педагогічної літературі. Окремі відомості з даної проблеми є в роботах ряду дослідників (В. В. Баркасі, С. Бондар, М. Головань, I. О. Зимняя, Н. В. Кузьміна, А. К. Маркова та ін.). У свою чергу, деякі автори (Г. А. Гринюк, С. Ю. Ніколаєва, Ю. А. Ситна, Н. К. Скляренко, Сисоєва Е.Е, Шамов А.Н. та ін.), досить докладно розглядаючи навички, необхідні для викладачів іноземних мов, не розглядають докладно їх роль у формуванні професійно-педагогічної компетентності цих осіб.

Поняття «компетентність» i його різні часткові варіанти (професійна компетентність учителя, мовна компетентність і т.п.) в останні роки одержали широке поширення в сучасній українській в сучасній вітчизняній науковій літературі педагогічної літературі, присвяченій проблемам підготовки учителів іноземної мови (В. В. Баркасі, С.В. Будак, Т. А. Гринюк, О. О. Заболотська, С. Ю. Ніколаєва, Н. К. Скляренко, Л. П. Смелякова та ін.). Саме поняття 
«компетентність» в цілому можна трактувати як "Володіння знаннями, які дозволяють міркувати про що-небудь, висловлювати вагому, авторитетну думку" $[1,2]$. Однак стосовно будь-якої професійної діяльності воно не отримало однозначного визначення в сучасній вітчизняній науковій літературі. Проблемам його тлумачення та використання в цій області, включаючи і педагогічну діяльність, присвячені спеціальні роботи (С. Бондар, М. Головань, І. Чемерис та ін.) Проте, майже всі фахівці погоджуються 3 тим, що компетентність, в тому числі й професійно-педагогічна компетентність - складне інтегративне явище, що включає в себе різні елементи. Порівняльний аналіз всієї сукупності цих різнорідних елементів, які пропонуються різними авторами (В. В. Баркасі, С. Бондар, I. О. Зимняя, Н. В. Кузьміна, А. К. Маркова, О. Я. Савченко, А. Хуторська, I. Чемерис та ін.) не входить у завдання нашої роботи. У цій статті розглядається, в першу чергу, місце педагогічних навичок у структурі професійної компетентності педагогів - викладачів іноземних мов. Ряд дослідників при визначенні компетентності вказують, що вона, в якості однієї із складових, безпосередньо включає в себе певні навички. Подібної точки зору дотримуються деякі західні (Дж.Рамен, Е. Шорт), російські (А. Хуторська) i українські (С. Бондар, М. Головань) автори. Так, Дж. Рамен розглядає компетентність як особливу здатність, необхідну для якісного виконання конкретних дій у конкретній предметній галузі. На його думку, компетентність включає в себе вузькоспеціалізовані знання і відповідні навички роботи, способи мислення та розуміння особистої відповідальності за результати своїх дій [3]. 3 подібною позицією згоден i М. Головань, який у якості одного 3 визначень компетентності пропонує наступне: «компетентність - це інтегратівне утворення особистості, що інтегрує в собі знання, уміння, навички, досвід і особистісні властивості, як обумовлюють прагнення, здатність і готовність розв'язувати проблеми і завдання, що виникають в реальних... ситуаціях..» [4].

Мета статті - визначення місця педагогічних навичок у структурі професійної компетентності майбутніх викладачів іноземної мови.

Виклад основного матеріалу. Більшість інших фахівців у визначення поняття «компетентність» беспосередньо навички не включають, але лише розуміють їх, як якусь другорядну складову цього феномену (В. В. Баркасі, П. П. Борисов, С. У. Гончаренко, О. М. Дахін, Н. В. Кузьміна, А. К. Маркова О. Я. Савченко, I. Чемерис та ін). Зазвичай в цьому визначенні вони згадують тільки про знання та уміння. Н. В. Кузьміна вперше запровадила в науковий обіг поняття "професійно-педагогічна компетентність". На іï думку, - це "система знань та умінь педагога, які виявляються при вирішенні на практиці професійнопедагогічних завдань" [5]. У свою чергу, А. Гуржій та В. Гапон розуміють компентність як сукупність знань та умінь, необхідних для професійної діяльності [6]. Разом з тим, С. У. Гончаренко, підкреслював, що вміння - це «засвоєний суб'єктом спосіб виконання дій, який забезпечує сукупність набутих 
знань та навичок» [7]. Таким чином, на думку більшості перерахованих вище авторів, навички лише частково включені в поняття компетентності.

Подібний підхід до визначення ролі навичок у структурі професійної компетентності передбачає виділення певних провідних структурних компонентів професійної компетентності, які, в свою чергу, містять в собі, іноді латентно, ті чи інші професійно- значущі навички. По відношенню до подібної диференціації думки фахівців дещо розходяться. Так, I. О. Зимняя вважає, що професійна компетентність включає мотиваційний (готовність до професійної діяльності), когнітивний та поведінковий (здатність проявити необхідну компетентність в реальних ситуаціях) компоненти [5]. Звідси безпосередньо випливає наявність певних професійних навичок у когнітивному та поведінковому компонентах професійної компетентності. Інший підхід до структуризації професійної компетентності пропонує В. В. Баркасі [1]. Розглядаючи структуру професійної компетентності учителів іноземної мови, вчена включає в неї наступні компоненти: соціальний, полікультурний, аутопсихологічній, когнітівно-технологічний і персональний. При цьому автор наголошує, що «першим компонентом професійної компетентності майбутніх учителів іноземних мов $є$ когнітівно-технологічний» [8]. Саме когнітивнотехнологічний компонент професійної компетентності викладачів іноземних мов, на думку дослідника, включає в себе більшість професійних навичок. У свою чергу, С. Бондар вважає, що в структурі професійної компетентності містяться: потребо-мотіваційна, когнітівна, операційно-діяльнісна, практична та рефлексивна складові [8]. I тут можна зробити висновки, що різні професійні навички входять до складу останніх чотирьох складових професійної компетентності.

Таким чином, в даний час у вітчизняній та світовій педагогіці та психології не існує єдиного підходу до визначення місця професійно значущих навичок у структурі професійної компетентності. Повною мірою це відноситься i до професійно-педагогічної компетентності викладачів іноземних мов. Ми вважаємо, що педагогічні навички викладача іноземних мов повинні, в першу чергу, включати в себе:

- навички володіння іноземною мовою;

- навички викладання іноземної мови;

- загальнопедагогічні навички.

Подібне диференціювання певною мірою можна співвіднести 3 компонентами професійної компетентності, виділеними різними перерахованими вище авторами. Так, навички володіння іноземною мовою i навички його викладання входять до когнітивно-технологічного компоненту професійнопедагогічної компетентності, виділеного В. В. Баркасі [9]. Вона під піi технологічною складовою розуміє володіння різними педагогічними технологіями. Також, представляється можливим включити в когнітивний 
компонент професійної компетентності, запропонований С. Бондар, навички володіння іноземною мовою [10]. Трохи складніше йде справа 3 загальнопедагогічними навичками. Деякі з них можуть входити як в когнітивний, так і в інші компоненти професійної компетентності, наприклад, в «практичний» (С. Бондар), «поведінковий» (І. О. Зимняя) або в «соціальний» (В. В. Баркасі ). Можна припустити, що тільки виділення педагогічних навичок у самостійну складову професійної компетентності вчителів дозволить чітко й однозначно визначити їх значення в структурі цього інтегративного поняття. Це зумовлено, по-перше, тим, що підвищення професійної компетентності неможливе без продуктивної практичної діяльності. А вона в свою чергу, багато в чому залежить від оволодіння відповідними навичками, без яких, навіть у випадку оволодіння знаннями й уміннями, така діяльність буде малоефективною. По-друге, нелінійна взаємодія надбаних професійних знань, умінь та навичок у процесі формування $\mathrm{i}$ вдосконалення професійної компетентності зумовлює необхідність розглядати їх як самостійні, хоча і взаємопов'язані феномени. По-третє, як було показано вище, різні навички можуть входити в різні компоненти професійної компетентності. Таким чином, професійні навички, в тому числі й педагогічні, відіграють самостійну і досить важливу роль у структурі професійної компетентності [11].

Зрозуміло, що подібну конструкцію не можна назвати універсальною. Однак вона, принаймні, помітно спрощує докладний аналіз місця i ролі різних педагогічних навичок, як безпосередніх елементів професійної компетентності викладачів іноземних мов [12].

Розглянемо кожен 3 вищезазначених видів педагогічних навичок. У вітчизняній педагогічній науці особливу увагу формуванню навичок володіння іноземною мовою в процесі навчання стали приділяти в середині XX ст. Так, С. К. Фоломкіна, пояснюючи це педагогічне явище, ще в 1950 р. писала, що репродуктивне володіння іноземною мовою включає в себе знання, уміння та навички, тобто «отримані мовні знання та уміння повинні бути доведені до ступеня автоматизації». Пізніше проблема класифікації та формування навичок володіння іноземними мовами та їі окремі аспекти розглядалися в роботах цілого ряду фахівців (Г. А. Гринюк, С. Ю. Ніколаєва, Ю. А. Ситна, Н. К. Скляренко, Сисоєва Е.Е., Шамов А.Н. та ін.) Це, в першу чергу, стосується перцептивних (техніка читання), слухових (фонетичних та інтонаційній слух), вимовних (артікуляційні та інтонаційні), та каліграфічних та орфографічних (техніка писання) навичок. В наш час подібні дослідження активно продовжуються.

Дещо менше уваги фахівці приділяють формуванню у студентів і учителів спеціальних навичок викладання іноземної мови. Як правило, це проблема фрагментарно і посередньо розглядається в дослідженнях з використання різних педагогічних технологій у сфері навчання іноземних мов (Ю. А. Ситна, Л. В. Сухова, А. Н. Шамов, А. Н. Щукін та ін.). 
Що ж стосується загальнопедагогічних навичок, настільки необхідних

учителям іноземної мови, то до них можна віднести традиційні в педагогіці навички викладачів: комунікативні, пов'язані з саморегуляцією та психологічною стійкістю, що забезпечують впевнене використання різних інформаційних технологій і т.п. Втім у цій галузі слід звернути особливу увагу на комунікативні навички. Це поняття може бути використане в двох значеннях. По-перше, у більш широкому сенсі воно пов'язане з педагогічною комунікацією у цілому, тобто із здатністю забезпечити ефективне педагогічне спілкування викладачів 3 учнями. По-друге, комунікативні якості та пов'язані 3 ними навички викладачів іноземних мов можна розуміти і в більш вузькому сенсі, тобто як здатність забезпечити іноземною мовою: «продукування текстів різної стильової та змістової спрямованості; переформулювання інформації без втрати чи спотворення сенсу; комфортність інтонації та високу швидкість мовлення» [13]. Таким чином, комунікативні навички викладачів іноземних мов можна віднести як до загальнопедагогічних навичок, так і до навичок володіння іноземними мовами і викладання іноземних мов.

Висновки. Аналіз сучасної науково-педагогічної літератури показує, що в питанні визначення педагогічних навичок, як елементів професійної компетентності викладачів, в тому числі і учителів іноземної мови, у вчених немає єдиної думки. Можна припустити, що виділення педагогічних навичок у самостійну складову професійної компетентності вчителів дозволить чітко й однозначно визначити їх значення та функції в структурі цього інтегративного поняття.

\section{Лimepamypa:}

1. Баркасі В.В. Формування професійної компетентності в майбутніх учителів іноземних мов: дис. ... кандидата пед. наук : 13.00 .04 / Баркасі Вікторія Володимирівна - Одесса : Південноукраїнський державний педагогічний університет ім. К.Д. Ушинського, 2004. - 183 с.

2. Бондар С. Термінологічний аналіз понять «компетенція» і «компетентність» у педагогіщі: сутність та структура / С. Бондар // Освіта і управління. - 2007. - Т.10. - №2. - С. 93 - 99.

3. Головань М. Компетенція і компетентність: досвід теорії, теорія досвіду / М. Головань// Вища освіта України. - 2008. - №3. - С. 23 - 29.

4. Гончаренко С.У. Український педагогічний словник / С.У. Гончаренко. - К. : Либідь, 1997. $-375 \mathrm{c}$.

5. Гуржий А. Методологічні засади оцінювання та прогнозування розвитку вищої освіти України / А. Гуржий, В. Гапон // Вища освіта України. - 2006. - №1 - С. 23 - 31.

6. Ніколаєва С.Ю. Методика викладання іноземних мов у середніх навчальних закладах / С.Ю. Ніколаєва. - К. : Ленвіт, 2002. - 328 с.

7. Рамен Джон. Компетентность в современном обществе: выявление, развитие и реализация / Джон Рамен. - М.: Когито-Центр, 2002. - 396 с.

8. Ситнов Ю.А. Грамматические навыки, знания и умения в свете теории когнитивизма / Ю.А. Ситнов // Иностранный язык в школе. - 2005. - №7. - С. 42 - 48.

9. Сухова Л.В. Коммуникативно-ориентированное обучение иностранному языку и языковая парасреда как его системообразующий фактор / Л.В. Сухова // Иностранный язык в школе. - 2007. - №4. - С. 15 - 18. 
10. Чемерис I. Нові вимоги до спеціаліста: поняття компетентності й компетенції / I. Чемерис // Вища освіта України. - 2006. - №2. - С. 84 - 87.

11. Щукин А.Н. Новый метод интенсивного обучения / А.Н. Щукин // Иностранный язык в школе. - 2007. - №4. - С. 106 - 108.

12. Курепін В.М. Використання дистанційного навчання в освітньому процесі спеціальних груп закладів професійної (професійно-технічної) освіти / В.М. Курепін, Д.Д. Марченко // Перспективи та інновації науки (Серія «Педагогіка», Серія «Психологія», Серія «Медицина»). 2021. - № 2(2). - C. 73 - 83. DOI: https://doi.org/10.52058/2786-4952-2021-2(2)-73-83.

13. Матвєєва К.С. Напрямки роботи сімейного педагога у структурі територіального центру соціальної допомоги сім’ї та дітям / К.С. Матвєєва, Д.Д. Марченко, В.М. Курепін // Перспективи та інновації науки (Серія «Педагогіка», Серія «Психологія», Серія «Медицина»). - 2021. - № 2(2). - C. 84 - 97. DOI: https://doi.org/10.52058/2786-4952-2021-2(2)-84-97.

\section{References:}

1. Barkasi V.V. (2004). Formuvannya profesiynoyi kompetentnosti v maybutnikh uchyteliv inozemnykh mov [Formation of professional competence in future teachers of foreign languages]. Odessa : Pivdennoukrayins'kyy derzhavnyy pedahohichnyy universytet im. K.D. Ushyns'koho [in Ukrainian].

2. Bondar S. (2007). Terminolohichnyy analiz ponyat' «kompetentsiya» $i$ «kompetentnist'» $u$ pedahohitsi: sutnist' ta struktura [Terminological analysis of the concepts of "competence" and "competence" in pedagogy: essence and structure]. Osvita i upravlinnya [in Ukrainian].

3. Holovan' M. (2008). Kompetentsiya i kompetentnist': dosvid teoriyi, teoriya dosvidu [Competence and competence: experience of theory, theory of experience]. Vyshcha osvita Ukrayiny [in Ukrainian].

4. Honcharenko S.U. (1997). Ukrayins'kyy pedahohichnyy slovnyk [Ukrainian pedagogical dictionary]. Kyiv : Lybid' [in Ukrainian].

5. Hurzhyy A. (2006). Metodolohichni zasady otsinyuvannya ta prohnozuvannya rozvytku vyshchoyi osvity [Methodological principles of evaluation and forecasting of higher education of Ukraine]. Ukrayiny Vyshcha osvita Ukrayiny [in Ukrainian].

6. Nikolayeva S.YU. (2002). Metodyka vykladannya inozemnykh mov u serednikh navchal'nykh zakladakh [Methods of teaching foreign languages in secondary schools]. Kyiv : Lenvit [in Ukrainian].

7. Ramen Dzhon (2002). Kompetentnost' v sovremennom obshchestve: vyyavlenye, razvytye y realyzatsyya [Competence in modern society: identification, development and implementation]. Moscow : Kohyto-Tsentr [in Russian].

8. Sytnov YU.A. (2005). Hrammatycheskye navyky, znanyya y umenyya $v$ svete teoryy kohnytyvyzma [Grammatical skills, knowledge and abilities in the light of the theory of cognitivism]. Ynostrannyy yazyk v shkole [in Ukrainian].

9. Sukhova L.V. (2007). Kommunykatyvno-oryentyrovannoe obuchenye ynostrannomu yazyku y yazykovaya parasreda kak eho systemoobrazuyushchyy faktor [Communicative-oriented learning of a foreign language and language parasreda as its system-forming factor]. Ynostrannyy yazyk v shkole [in Ukrainian].

10. Chemerys I. (2006). Novi vymohy do spetsialista: ponyattya kompetentnosti y kompetentsiyi [New requirements for the specialist: the concept of competence and competence]. Vyshcha osvita Ukrayiny [in Ukrainian].

11. Shchukyn A.N. (2007). Novyy metod yntensyvnoho obuchenyya [A new method of intensive training]. Ynostrannyy yazyk v shkole [in Ukrainian].

12. Kurepin V.M. \& Marchenko D.D. (2021). Vykorystannya dystantsiynoho navchannya $v$ osvitn'omu protsesi spetsial'nykh hrup zakladiv profesiynoyi (profesiyno-tekhnichnoyi) osvity [The use of distance learning in the educational process of special groups of institutions of professional (vocational) education]. Perspektyvy ta innovatsiyi nauky (Seriya «Pedahohika», Seriya 
«Psykholohiya», Seriya «Medytsyna») [in Ukrainian]. DOI: https://doi.org/10.52058/2786-49522021-2(2)-73-83.

13. Matvyeyeva K.S., Marchenko D.D. \& Kurepin V.M. (2021). Napryamky roboty simeynoho pedahoha u strukturi terytorial'noho tsentru sotsial'noyi dopomohy sim"yi ta dityam [Directions of work of a family teacher in the structure of the territorial center of social assistance to families and children]. Perspektyvy ta innovatsiyi nauky (Seriya «Pedahohika», Seriya «Psykholohiya», Seriya «Medytsyna») [in Ukrainian]. DOI: https://doi.org/10.52058/2786-4952-2021-2(2)-84-97. 